\title{
The Study of Entrepreneurship and Innovation Adoption by Farmer in Improving Lowland Rice Farming
}

\author{
Muhammad Fauzan Umar*, Iwan Nugroho, Darmadji, and Suwarta
}

Agribusiness Department, Widyagama University of Malang, Indonesia

(Received March 5, 2020; Accepted April 7, 2020; Published April 22, 2020)

\begin{abstract}
The study of entrepreneurship and the adoption of innovations in farming so far shows a onesided approach using a single equation model. It is not able to explore more in-depth information to improve farm management. This study aims to study (i) the performance of farming, (ii) the role of entrepreneurship and the adoption of innovative tractor use, and (iii) find the relationship between entrepreneurship, adoption of innovation, and the application of cultivation technology to the performance of lowland rice farming. The study was conducted in the village of Mattiro Ade, Patampanua sub-district, Pinrang Regency, South Sulawesi province. The survey was done on 50 lowland rice farmers who applied the tractor and combine harvester technology. The study used a descriptive approach and the method of path analysis (partly least square). The results show that the technology of tractor and combine harvester could improve farming performance, with an average yield of 6.62 tons of rice per hectare, a profit of 21.9 million rupiahs per hectare, with an $\mathrm{R} / \mathrm{C}$ ratio of 3.21 . The farmers showed perceptions of entrepreneurship and technology adoption at moderate levels. They also had limitations regarding the access to information, loans or venture capital, and training in the use of tractors. The adoption of innovations by the farmers dealt with obstacles in terms of tractor operations, tractor prices, and the weak role of farmer groups. Entrepreneurship and technology adoption had a significant role in increasing the performance of lowland rice farming, where technology played a role as an intervening variable. This research has important implications, namely the provision of extension workers and the empowerment of farmer groups to facilitate technology adoption and increase entrepreneurial entrepreneurship in farm management.
\end{abstract}

Keywords: combine harvester, farm management, innovation adoption, lowland rice, Pinrang

JEL Classification: L26, O35, Q12

\section{INTRODUCTION}

Works to increase farming intensification are carried out through improving cultivation technology and empowering farmers. This effort can be done through the provision of production factors such as seeds, fertilizers, and pesticides (Efendy \& Hutapea, 2014; Heryono, Nugroho, \& Hanafie, 2016; Suhendrata, 2010), or mentoring by extension workers (Aminah, Sumardjo, Lubis, \& Susanto, 2015; Fangohoi, Sugiyanto, Sukesi, \& Cahyono, 2018; Herlina, 2014). The effort is also a learning process for farmers to have independence

\footnotetext{
* Corresponding author email: fauzanumar43@gmail.com ISSN 2615-6075 online; ISSN 2615-6946 print @UWG Press, 2020

OJS http://publishing-widyagama.ac.id/ejournalv2/index.php/jsed/
}

and be able to reason and make decisions in farming. In an increasingly modern era, sources of information about farming have become more open and massive, and this has become a provision for farmers to run farming and enjoy welfare for the benefit of their household.

The independence of farmers in running a farming business is essential in their lives. Farmers need to be independent and be able to break away from traditional management in farming. They need to learn more advanced farm management, follow developments, dare to face risks, and use more efficient technologies in farming (Rangkuti, 2010; Widiyanti, Karsidi, Wijaya, \& Utari, 2019). In other words, farmers need to recognize farming positively, apply entrepreneurial principles and adopt new technologies in farm businesses. 
Entrepreneurship and innovation are critical concepts for increasing productivity. Entrepreneurship is one of the factors that make the production function (Darmadji \& Suwarta, 2018), going beyond the classical concepts of production theory, such as Cobb-Douglas. Darmadji \& Suwarta (2018) worked to improve the conception of production functions, and build model relationships between management factors, technology, and entrepreneurship on-farm performance. Meanwhile, entrepreneurship can develop one's creativity to find ideas and opportunities to innovate, work in teams, and create productive values and culture (Gundry, Ofstein, \& Kickul, 2014). Entrepreneurship functions as a medium for the development of technological innovation (Boso, Cadogan, \& Story, 2013; Wei, Liu, \& Sha, 2019), as well as opening capital and market opportunities to encourage business or organizational performance (Lisa, 2019; Sulistyo \& Siyamtinah, 2016).

Building a culture of entrepreneurship among farm households is not easy. It is related to the viewpoints, habits and traditional values of rural life. Building a culture of entrepreneurship is easier for economic actors in urban or business organizations. Farmers need to open themselves to the development of information technology and obtain counseling assistance (Bakhtiar \& Novanda, 2018; Rangkuti, 2010). In general, young generation farmers have a more positive outlook in carrying out agribusiness management (Widiyanti et al., 2019). A specific approach is needed to empower farmers and build an entrepreneurial spirit, for example, field schools, training, technology introduction, dissemination, or mentoring (Waddington et al., 2014).

Efforts in improving lowland rice farming in Indonesia continue to be done. They are carried out by farmers and supported by various government policies. Rice is a strategic commodity, so the observation of its dynamics and development is always prioritized. A development planning related to rice production or consumption has always been a concern (Triyono, Laksani, Zulhamdani, Nadhiroh, \& Ariana, 2018). As a result, this has increased the average rice productivity from 4.38 tons per hectare in 1993 to 53.4 tons per hectare in 2015. During these periods, national rice production increased from 48.1 to 75.4 million tons (BPS, 2019).

Agricultural technology innovation has an essential position in increasing national rice production to achieve food self-sufficiency. However, technology adoption is affected by many factors. Given studies of rice farmers in South Sumatra (Efendy \& Hutapea, 2014), technology adoption is affected by exposure of technology, farmer's cosmopolite, trialability, technological complexity and the role of extension workers. Adoption of technology is more acceptable to farmers who are relatively young and educated (Sudana \& Subagyono, 2012), who are active in farmer groups, have good communication, and are eager to get information (Harinta, 2011). In contrast, farmers are not interested in adopting technologies that are operationally complicated to work with (Hasbi \& Tunggal, 2019).

Tools and machines encourage efficiency and other benefits in rice farming. The use of hand tractor machines in the Banten area, on average, saves work time as much as 7.8 hours a workday, saving costs 400 thousand rupiahs per hectare, and generates a profit of 800 thousand rupiahs per hectare compared to the manual method (Amrullah \& Hadi, 2016). A study (Suyatno, Imelda, \& Komariyati, 2018) shows that tractor machine in land management can increase productivity by 667 $\mathrm{kg}$ per hectare, and increase income by 2,843 million rupiahs per hectare. Bachrein, Ruswandi, \& Subarna (2009) revealed that tractor supply services have grown, with farmer participation above $96 \%$, generating a revenue-cost ratio of 1.36 and a payback period of 2.74 per year, and a break-even point of 30.77 ha per year. In general, tools and machinery can encourage efficiency in farming, save water and labor, and increase the intensity of rice cultivation (Amrullah \& Hadi, 2016).

The study of entrepreneurship and innovation in farming as described earlier is a more one-sided approach. Such integrated studies on farming have not been much studied. The study also focused more on the performance of business ventures or organizations. Exploring the role of entrepreneurship and innovation adoption integrally in rice farming is a challenge. It is expected to provide a more comprehensive perspective in the efforts to increase rice productivity, which so far 
has examined entrepreneurship and innovation incompletely.

One of the main rice-producing provinces is South Sulawesi. The province produced 5.74 million tons of rice or contributed around $10 \%$ of national production in 2018. Tractors for land management and general harvest were used by most farmers, especially in Pinrang regency. Pinrang is also the main rice production center along with Bone and Wajo regency. The average productivity of lowland rice in Pinrang district is 6.54 tons per hectare.

This research focuses on the study of the use of the tractor and combine harvester technology in lowland rice farming in the village of Mattiro Ade, Patampanua district, Pinrang Regency. The villagers have long worked intensively on rice farming. They are highly responsive to new technologies, and shows an entrepreneurial attitude.

This study aims to study (i) the performance of farming, (ii) the role of entrepreneurship and innovation adoption in the use of tractors and combine harvester, and (iii) the relationship between entrepreneurship, innovation, and the application of cultivation technology to the performance of lowland rice farming.

\section{RESEARCH METHOD}

This research was conducted in the village of Mattiro Ade, Patampanua district, Pinrang Regency, South Sulawesi province. The basis for the consideration of the location is a village that mainly produces rice. In addition, the farmers in the village have applied machine technology in the land management and rice production harvest.

The study used a survey approach that randomly selected 50 farmer respondents. The farmers' experiences are explored, regarding the use of the tractor and combine harvester technology in rice farming. The observed variables were the perception of entrepreneurship, innovation adoption, cultivation technology, respondent characteristics, and farming business performance.

Entrepreneurship variables were the indicators of (i) information acquisition, (ii) capital use, (iii) seed use, (iv) rice marketing, and (v) tractor use training. Variables of innovation adoption were the indicators of (i) knowledge of tractors, (ii) skill of operating tractors, (iii) tractor prices, (iv) tractor availability, (v) the role of farmer groups, (vi) village infrastructure. Indicators in entrepreneurship and innovation adoption variables were measured through a Likert scale (ordinal scale). Questions in the questioner provide five answer choices, including strongly agree (5), agree (4), moderate (3), disagree (2), and strongly disagree (1).

The cultivation technology variable was calculated by the cost per ha related to the use of (i) fertilizer, (ii) pesticides, (iii) land tillage, (iv) seed, and ( $v$ ) harvest work. Variable characteristics of farmer respondents were the indicators (i) land area (ha), (ii) age (years), (iii) education, and (iv) length of farming (years). The variable of farming business performance was appraised by indicators (i) productivity ( $\mathrm{kg} / \mathrm{ha}$ ), (ii) income (rupiah per ha), and (iii) profit (rupiah per ha). Indicators of technology variables, respondent characteristics, and farm performance were determined through a ratio scale, except education on an ordinal scale.

Table 1. The Determination of Score Categories

\begin{tabular}{lc}
\hline Scale of answer & Category \\
\hline $1.00-2.00$ & Very low \\
$2.01-3.00$ & low \\
$3.01-4.00$ & Moderate \\
$4.01-5.00$ & High \\
\hline
\end{tabular}

Sources: Sugiyono (2016)

The descriptive analysis method was done to get a picture of variable perception, especially for entrepreneurship and innovation adoption. Descriptive analysis works on the categorization of respondents' answers, following Sugiyono (2016). In categorizing the answer, the interval scale was counted from the highest score (5), subtracted by the lowest score (1), then the result was divided into four categories. The classification of respondents' answers is shown in Table 1.

The analysis method used was path analysis (partly least square, PLS), which was processed using SmartPLS 3.2.6 software application. Hypothetical models of relationships between variables are adapted using the conception (Boso et al., 2013; Darmadji \& Suwarta, 2018; Harinta, 2011; Sudana \& Subagyono, 2012; Wei et al., 2019) with slight adjustments (Figure 1). Modeling formulation was carefully carried out to meet 
proper research designs, and to apply reasonable indicator measurements (Angrist \& Pischke, 2008, 2010). Thus, the model would provide key parameters for the interest of decision making, despite of a limited number of samples.

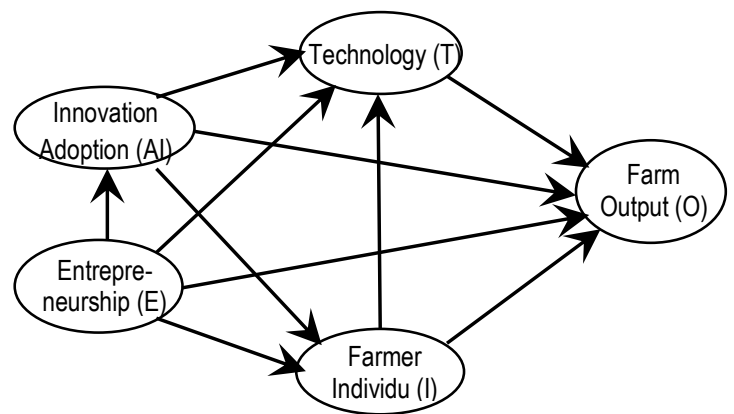

Figure 1. Hypothetical model of relationships between variables

\section{RESULT AND DISCUSSION}

\section{General Description of The Study Area}

Pinrang regency is $185 \mathrm{~km}$ distance from Makassar city to the north, bordering the province of West Sulawesi. It is a vital rice-producing area, having production areas in almost all of its districts. Rice productivity is relatively high at around 6.45 tons per hectare (Table 2).

The research area is in the village of Mattiro Ade, Patampanua district, Pinrang regency. The geographical position is $3.746,119.623$, at an altitude of 12 to $20 \mathrm{~m}$ above sea level. The size area of the village is around 868 hectares, dominated by lowlands. The population in 2018 is 4178 people (BPS Kabupaten Pinrang, 2019). The village in Mattiro Ade is passed by a provincial road where the area is developing service and trade activities to serve the surrounding area.

In this village, the cultivation of lowland rice was carried out very intensively, supported by wellmanaged irrigation infrastructure. Lowland rice cultivation had been going on since the Dutch colonial era, and irrigation channels had been constructed in the management of the Sadang catchment area. Government programs related to increasing food production were well implemented, including the application of agricultural tools and machinery. Farmers had implemented tractors for tillage and combine harvester for rice.

Table 2. Harvested Area and Rice Production by Municipal/Regency in South Sulawesi Province in 2018

\begin{tabular}{|c|c|c|c|}
\hline Municipal/Regency & $\begin{array}{c}\text { Harvested } \\
\text { area }\end{array}$ & Production & Productivity \\
\hline & $\mathrm{Ha}$ & Ton & Ton/Ha \\
\hline Kepulauan Selayar & 4429 & 22403 & 5.06 \\
\hline Bulukumba & 36408 & 193585 & 5.32 \\
\hline Bantaeng & 13997 & 73722 & 5.27 \\
\hline Jeneponto & 19408 & 96285 & 4.96 \\
\hline Takalar & 22453 & 110145 & 4.91 \\
\hline Gowa & 58981 & 292156 & 4.95 \\
\hline Sinjai & 22734 & 128777 & 5.67 \\
\hline Maros & 52414 & 309209 & 5.90 \\
\hline Pangkep & 24418 & 131760 & 5.40 \\
\hline Barru & 17821 & 104213 & 5.85 \\
\hline Bone & 170238 & 809402 & 4.76 \\
\hline Soppeng & 38568 & 225248 & 5.84 \\
\hline Wajo & 124739 & 619693 & 4.97 \\
\hline Sidrap & 83075 & 534473 & 6.43 \\
\hline Pinrang & 101384 & 654290 & 6.45 \\
\hline Enrekang & 10487 & 44079 & 4.20 \\
\hline Luwu & 61898 & 305151 & 4.93 \\
\hline Tana Toraja & 22670 & 100692 & 4.44 \\
\hline Luwu Utara & 38940 & 178243 & 4.58 \\
\hline Luwu Timur & 37642 & 209242 & 5.56 \\
\hline Toraja Utara & 23264 & 102913 & 4.42 \\
\hline Makassar & 3315 & 12490 & 3.77 \\
\hline Pare Pare & 954 & 5349 & 5.61 \\
\hline Palopo & 5098 & 28631 & 5.62 \\
\hline Total & 995335 & 5292152 & 5.32 \\
\hline
\end{tabular}

Source: (BPS South Sulawesi, 2016)

Table 3. Harvested Area and Rice Production by District in Pinrang Regency in 2016

\begin{tabular}{lcc}
\hline District & Harvested area & Production \\
\hline & Ha & Ton \\
Suppa & 2022 & 11906 \\
Mattiro Sompe & 9646 & 56796 \\
Lanrisang & 8547 & 50325 \\
Mattiro Bulu & 11979 & 70532 \\
Watang Sawitto & 10523 & 61959 \\
Paleteang & 5070 & 29852 \\
Tiroang & 11271 & 66364 \\
Patampanua & 13062 & 76909 \\
Cempa & 10654 & 62731 \\
Duampanua & 14599 & 85959 \\
Batulappa & 3276 & 19289 \\
Lembang & 5552 & 32690 \\
\hline Total (Pinrang) & 106201 & 625312 \\
\hline
\end{tabular}

Source: (BPS Pinrang Regency, 2017) 


\section{Characteristics of Respondents}

The characteristic of respondents including age, education, areas of land ownership and length of experience in farming are presented in Table 3. The average age of farmer respondents was 42.8 years, mostly in the category of 21 to 40 years age group or equal to $44 \%$ of the respondent. Most farmers' education was at the senior high school level, which was $46 \%$. Observations in the field showed that higher education graduates were not interested in working on the farmland. The relatively young farmers having relatively high education had the potential to bring forward agricultural business farming, including using new technology (Sudana \& Subagyono, 2012).

Table 4. Characteristics of Respondents

\begin{tabular}{|c|c|c|c|}
\hline No & Item & $\begin{array}{l}\text { Number of } \\
\text { respondents }\end{array}$ & Proportion \\
\hline & & people & $(\%)$ \\
\hline \multirow[t]{6}{*}{1} & Age of farmer & & \\
\hline & $\leq 20$ years & 1 & 2 \\
\hline & $21-40$ years & 22 & 44 \\
\hline & $41-60$ years & 19 & 38 \\
\hline & $61-80$ years & 8 & 16 \\
\hline & Average (years) & 42.8 & \\
\hline \multirow[t]{4}{*}{2} & Education level & & \\
\hline & Elementary school & 10 & 20 \\
\hline & Yunior high school & 17 & 34 \\
\hline & Senior high school & 23 & 46 \\
\hline \multirow[t]{6}{*}{3} & Land size of farm & & \\
\hline & $0.10-0.50$ (ha) & 21 & 42 \\
\hline & $0.51-1.00$ (ha) & 21 & 42 \\
\hline & $1.10-1.50$ (ha) & 4 & 8 \\
\hline & $1.51-3.00$ (ha) & 4 & 8 \\
\hline & Average (ha) & 1.4 & \\
\hline \multirow[t]{5}{*}{4} & $\begin{array}{l}\text { Farming experience } \\
\text { period }\end{array}$ & & \\
\hline & $\leq 10$ years & 17 & 34 \\
\hline & $10-25$ years & 14 & 28 \\
\hline & 25 years or above & 19 & 38 \\
\hline & Average (years) & 20.4 & \\
\hline
\end{tabular}

Meanwhile, the average area size of land owned by farmers was 1.4 ha, and ownership of land was less than 1 ha is $84 \%$. The average farming experience of respondents was 20 years, while the majority respondents had around ten year experience, at $66 \%$. Farmers' land ownership in the village of Mattiro Ade generally came from the inheritance of parents. According to (Thorbecke \& Van Der Pluijm, 1993) the phenomenon of inheritance is commonly found in Indonesia, and generates small size plots of land reduced by 0.1 ha.

\section{Farm Business Performance}

Farm business performance is shown in Table 4. The data analysis meets the statistical test where the data are normally distributed and show significant variation. This study found that it produced an average productivity of 6.619 tons of rice per hectare. This figure is relatively high compared to the average productivity in Pinrang regency (6.45), South Sulawesi province (5.31), or national level (5.23) districts. However, the productivity is lower than the study (Heryono et al., 2016) of 7.28 tons per ha in lowland rice in Lumajang regency.

The average cost of paddy farming was 9.9 million rupiahs per hectare, and the average income was 31.8 million rupiahs per hectare. The result of the $R / C$ analysis was 3.21. This $R / C$ value was higher than the findings (Heryono et al., 2016) of 2.97. The results of this study yielded an average profit of 21.9 million rupiahs per hectare. Farmers with an area of 0.2 hectares, received the profit only about 4.2 million rupiahs per planting season or equal with 1.05 million rupiahs per month. The profit was relatively low to support the lives of farmers and their families.

In this study, the production cost data regarding the distributed tillage land was not normal. It relates to the use of the tractor and combine harvester machine, in which the cost of renting equipment was relatively equal among respondents due to the relatively small area of their land. In the village of Mattiro Ade, the combined harvester rental costs for rice harvest were at $11 \%$ of production. The range of rental costs ranged from 10 to $15 \%$ of production. This research shows that the adoption of the tractor and combine harvester technology can reduce the relative cost of production and increase the $\mathrm{R} / \mathrm{C}$ ratio.

\section{Entrepreneurship and Innovation Adoption}

Farmers' perceptions about entrepreneurship related to the use of technology in lowland rice cultivation are presented in Table 5. Entrepreneurial perceptions were measured through the ease of obtaining or accessing information, loans, seeds, yield marketing, and training. On average, farmers had the perceptions of entrepreneurship at a moderate level (3.21). Farmers showed a low perception of access to 
information, loans, and training, with scores of 2.26, 2.74, and 2.28, respectively. While high perceptions were shown regarding the access to seed (4.20) and yield marketing (4.58).

Access to information, loans and training were beyond the control of the farmers. It required greater effort in energy, creativity, learning and socializing. This step is a part of the entrepreneurial character (Gundry et al., 2014; Purnomowati \&
Nugroho, 2010). Farmers' access to capital will improve internal locus of control, improve their management capabilities, and ultimately improve the ability of agricultural entrepreneurs (Mumuni \& Oladele, 2016). Meanwhile, access of seeds and marketing was entirely controlled by farmers. Farmers used to save seeds or buy seeds at farm shops. In the village of Mattiro Ade, farmers usually sold rice to middlemen who were always ready to serve farmers.

Table 5. Farmers' Perceptions Regarding Entrepreneurship in Lowland Rice Farming

\begin{tabular}{|c|c|c|c|c|c|c|c|}
\hline \multirow{2}{*}{ No } & \multirow{2}{*}{ Indicator } & \multicolumn{5}{|c|}{ Respondent's Answer $^{\mathrm{a}}$} & \multirow{2}{*}{$\operatorname{Mean}^{\mathrm{b}}$} \\
\hline & & 1 & 2 & 3 & 4 & 5 & \\
\hline & & & & $\%$ & & & \\
\hline 1 & Easily access information about tractor technology & 6 & 74 & 10 & 8 & 2 & 2.26 \\
\hline 2 & Easily access capital / farm business loans & 6 & 22 & 64 & 8 & & 2.74 \\
\hline 3 & Easily obtain rice seeds & 4 & & 6 & 52 & 38 & 4.20 \\
\hline 4 & Easy to sell rice production (market) & & & 2 & 38 & 60 & 4.58 \\
\hline \multirow[t]{2}{*}{5} & Easy to get training in the use of tractor technology & & 74 & 18 & 8 & & 2.28 \\
\hline & Average & & & & & & 3.21 \\
\hline
\end{tabular}

${ }^{a}$ Answer questions, including 1: strongly disagree; 2: disagree; 3: moderate; 4: agree; and 5: strongly agree

${ }^{\mathrm{b}}$ Entrepreneurial classification, including $1.00-2.00$ : very low; $2.01-3.00$ : low; $3.01-4.00$ : moderate; and $4.01-$ 5.00: high

Table 6. Farmers' Perceptions Regarding the Adoption of Innovations in Lowland Rice Farming

\begin{tabular}{|c|c|c|c|c|c|c|c|}
\hline \multirow[b]{2}{*}{ No } & \multirow{2}{*}{ Indicator } & \multicolumn{5}{|c|}{ Respondent's Answer $^{\mathrm{a}}$} & \multirow{2}{*}{ Mean $^{b}$} \\
\hline & & 1 & 2 & 3 & 4 & 5 & \\
\hline & & \multirow{2}{*}{\multicolumn{3}{|c|}{........ }} & & & \\
\hline 1 & Already know the tractor technology & & & & 80 & 20 & 4.20 \\
\hline 2 & Able to operate new tractor technology & & 76 & 8 & 6 & 10 & 2.50 \\
\hline 3 & The price of the tractor is very affordable & 4 & 78 & 6 & 4 & 8 & 2.34 \\
\hline 4 & Tractors are available and can be purchased in the nearest city & & & 6 & 78 & 16 & 4.10 \\
\hline 5 & Farmer groups are very supportive of using technology & 2 & 72 & 12 & 14 & & 2.38 \\
\hline \multirow[t]{2}{*}{6} & Village infrastructure is adequate to support tractor operations & & 6 & 8 & 82 & 4 & 3.84 \\
\hline & 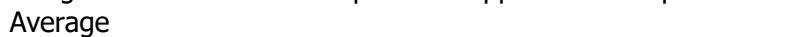 & & & & & & 3.23 \\
\hline
\end{tabular}

Farmers' perception regarding the innovation adoption of tractor technology in lowland rice cultivation is presented in Table 6. Perception of innovation adoption was measured through the ability to recognize technology, to operate the tractor, and through considering price perceptions, tractor availability, the role of farmer groups, and infrastructure facilities. On average, farmers showed the perception of adoption of innovation at a moderate level (3.23). Farmers showed low perceptions on indicators of tractor operations, prices, and the role of farmer groups, each with a value of $2.50,2.34$, and 2.38 , respectively. The high perception of the innovation adoption was in recognizing the tractor (4.20) and the availability of the tractor (4.10). The perception on availability of infrastructure was in the level of moderate (3.87).

Furthermore, there were some critical findings related to farmers' perception of the adoption of the tractor and combine harvester technology. The price of a combine harvester on the market was at least 30 million rupiahs. The machine could not be bought by small farmers whose land was less than one hectare. The probability of the farmers getting a tractor engine or combine harvester was in farmer groups. However, it was also not possible 
because the farmers' group did not function optimally. In the village, farmers could do a farming business independently, including renting the tractors and combine harvesters. Farmers generally tended to work individually, and they did not get guidance from extension workers.

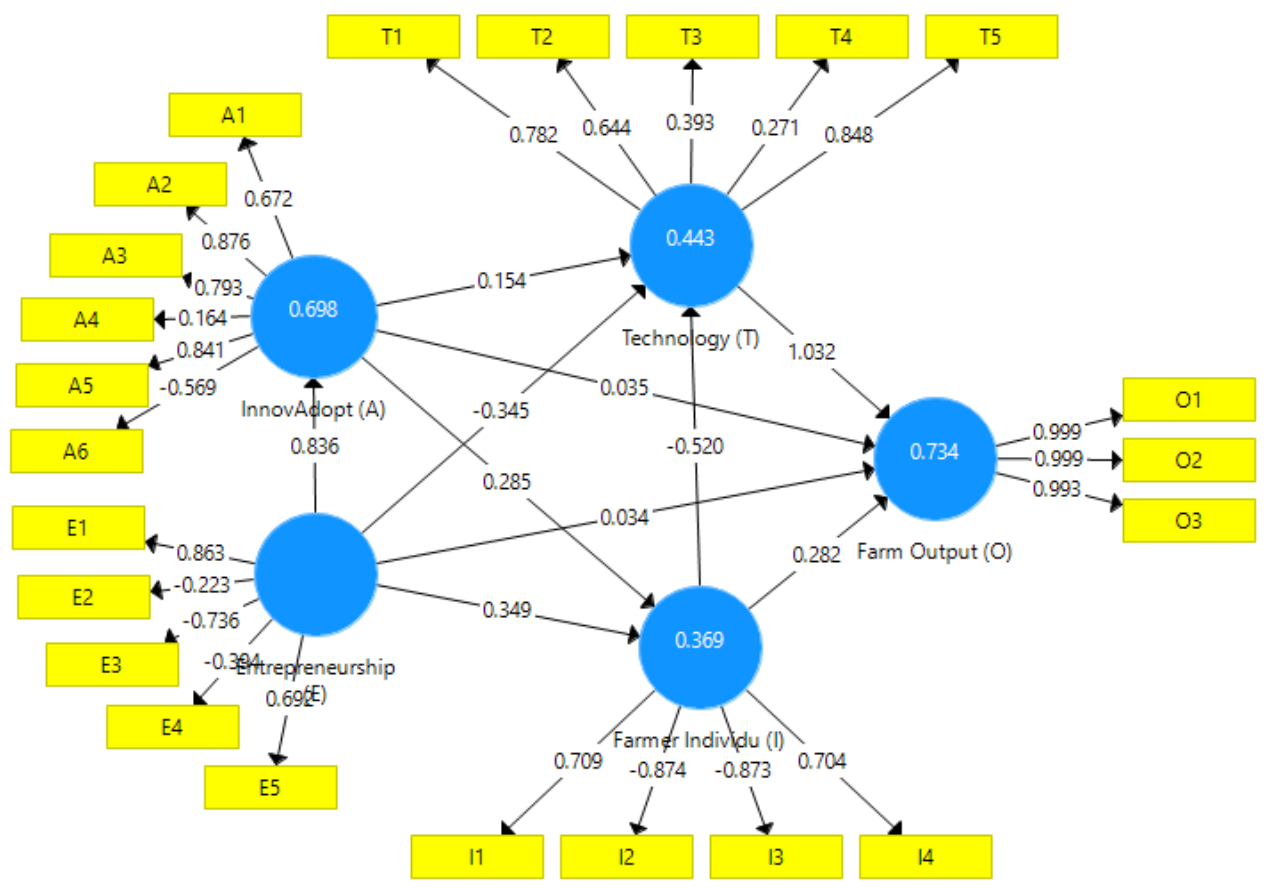

Figure 2. The initial model of variable relations

\section{Relationship of Entrepreneurship, Technology Adoption, and Farm Business Performance}

The conception of entrepreneurial relationships, technology adoption, and farming business performance expressed in the structural model is presented in Figure 2. The figure presents the relationship between latent variables and relationships with its indicators, based on the results of PLS analysis (partly least square, PLS) using SmartPLS 3.2.6 software application. The latent variables were entrepreneurship (E), adoption of innovation (A), technology $(T)$, the individual character of farmers (I), and farm business performance $(0)$.

The result of the PLS analysis shows the loading factor relationship between the indicator and its latent variables (Figure 2). Some indicators were found to have a loading factor of less than 0.6, namely E2, E4, A4, A6, T3, and T4, with values of -
$0,223,-0,394,0,164,-0,569,0,391$, and 0.271 . These indicators should be eliminated so that the model meets the requirements for use. The new model presented in Figure 3, shows a fairly high loading factor, close to or exceeding the threshold value of 0.70 . It means that indicators can explain or influence the character of latent variables so that all latent variables can work in the model.

The new model also needs to be tested for validity and reliability. Validity test used was Average Variance Extracted (AVE) to see convergent validity, while the reliability test used was Composite Reliability (CR). According to Ghozali (2006), this model is considered valid and reliable if AVE or CR exceeds the typical values of 0.50 and 0.70 , respectively. The test results show that all latent variables meet the requirements (Table 7). It means that the model can be worked to explain the model and its relationship with other latent variables. 
Table 7. Validity and Reliability Test of The Model ${ }^{\mathrm{a}}$

\begin{tabular}{lcc}
\hline Latent Variable & $\begin{array}{c}\text { Average } \\
\text { Variance } \\
\text { Extracted } \\
\text { (AVE) }\end{array}$ & $\begin{array}{c}\text { Composite } \\
\text { Reliability } \\
\text { (CR) }\end{array}$ \\
\hline Entrepreneurship (E) & 0.608 & 0.435 \\
Innovation adoption (A) & 0.659 & 0.885 \\
Technology (T) & 0.637 & 0.839 \\
Farmer as an individual (I) & 0.632 & 0.073 \\
Farm performance (O) & 0.993 & 0.998 \\
\hline aThe model is considered valid and reliable if AVE and CR \\
exceeds the ideal cut off values of 0.50 and 0.70
\end{tabular}

The relationship model also reveals several essential indicators that influence latent variables, in which the indicator shows a relatively high loading factor. Indicators of entrepreneurship variables that play an essential role are information about tractor technology (E1) and training (E5). Essential indicators of innovation adoption variables are the skill of operating tractors (A2), tractor prices (A3), and the role of farmer group (A5). The indicators of technology variable are contributed by fertilizers (T1), pesticides (T2), and harvesting work (T5). Indicators of individual farmer variables are age (I2) and education (I3). Finally, all indicators of farm business performance variables show a significant role, namely productivity (01), income (O2), and profit (O3).

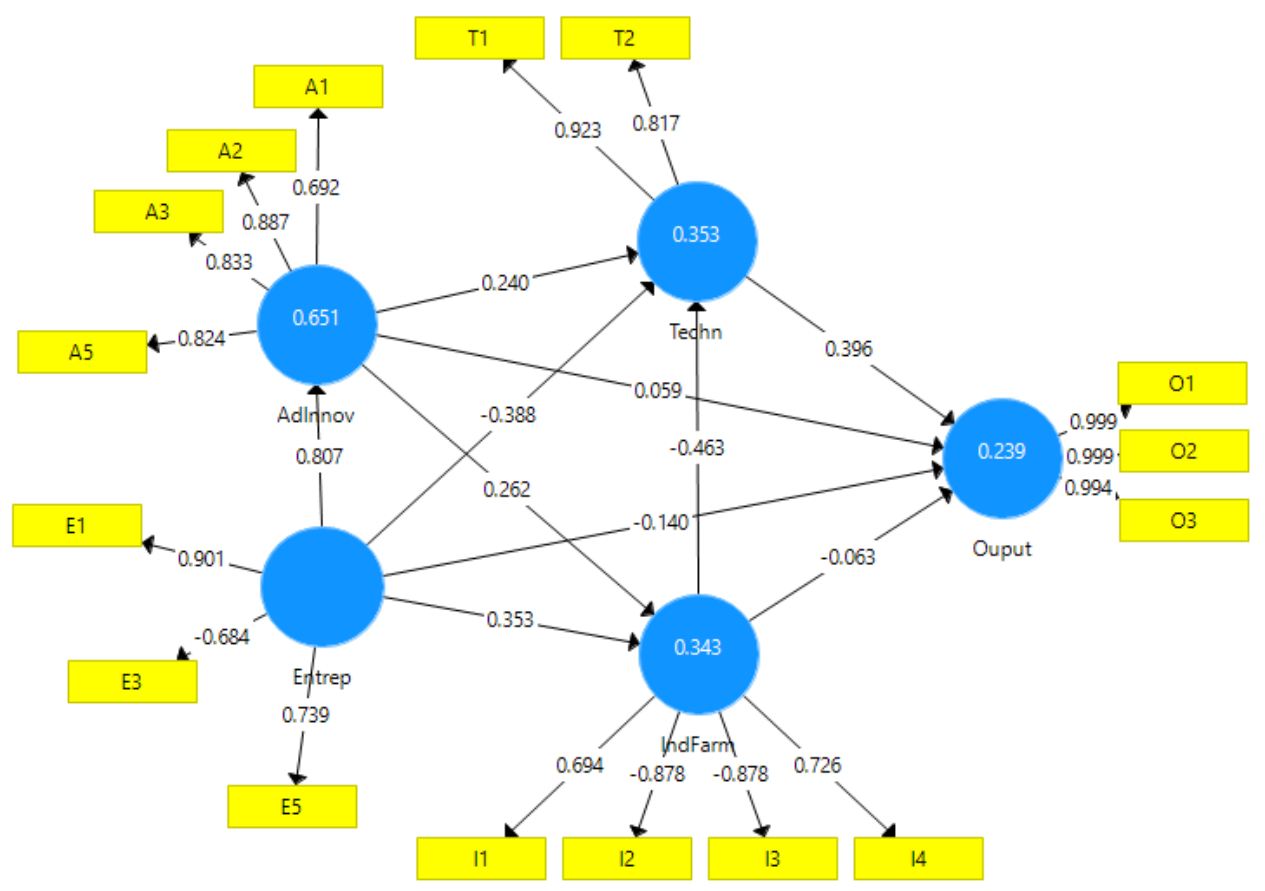

Figure 3. The modified variable relationship model

The next model test (Figure 3 ) is a hypothesis test of the relationship between latent variables as presented in Table 8. The significant relationship between variables ( $p$-value $<0.05$ ) is shown by Entrepreneurship (E) $\rightarrow$ Innovation adoption $(A)$, and Technology $(\mathrm{T}) \rightarrow$ Farm performance $(\mathrm{O})$. The relationships that need to be considered with a $p$ value above 0.05 are Entrepreneurship (E) $\rightarrow$ Technology $(T)$ ( $p$-value $=0.079)$, Innovation adoption $(\mathrm{A}) \rightarrow$ Technology $(\mathrm{T})$ ( $\mathrm{p}$-value $=0.387)$ and Individual Farmers $(\mathrm{I}) \rightarrow$ Technology $(\mathrm{T})(\mathrm{p}$ value $=0.359$ ). The last conceptual relationship is fulfilled, in which technology gives a significant role to improve the performance of rice farming (Amrullah \& Hadi, 2016; Efendy \& Hutapea, 2014).

The influence of entrepreneurship variables on innovation adoption and technology have been revealed by many researchers (Boso et al., 2013; 
Gundry et al., 2014; Wei et al., 2019). Likewise, the effect of technology on farm business performance is related to the efficiency and productivity improvement (Suyatno et al., 2018). Furthermore, the effect of entrepreneurship on technology and the influence of individual farmers on technology shows a significant negative coefficient. These prove that technology can reduce production costs (Amrullah \& Hadi, 2016; Suyatno et al., 2018), which in this study are measured by the costs of fertilizers, pesticides, tillage, seeds, and harvesting work. This research reveals that age and education indicators contribute significantly to the individual character of farmers. The higher age and education of farmers has a significant influence on the efficiency of farming technology, as stated by Sudana \& Subagyono (2012).

Table 8. The Estimate of Relationships Between Latent Variables ${ }^{a}$

\begin{tabular}{|c|c|c|c|}
\hline Latent variable & $\begin{array}{c}\text { Path } \\
\text { coefficient }\end{array}$ & t-test & $\mathrm{p}$-value \\
\hline Entrepreneurship $(E) \rightarrow$ Innovation adoption $(A)$ & 0.807 & 13.333 & 0.000 \\
\hline Entrepreneurship (E) $\rightarrow$ Technology $(T)$ & -0.391 & 1.759 & 0.079 \\
\hline Entrepreneurship $(\mathrm{E}) \rightarrow$ Farmer as Individual (I) & 0.357 & 0.863 & 0.389 \\
\hline Entrepreneurship (E) $\rightarrow$ Farm performance (O) & 0.081 & 0.733 & 0.464 \\
\hline $\begin{array}{l}\text { Innovation adoption }(\mathrm{A}) \rightarrow \text { Farmer as Individual } \\
(\mathrm{I})\end{array}$ & 0.264 & 0.700 & 0.484 \\
\hline Innovation adoption $(\mathrm{A}) \rightarrow$ Farm performance $(\mathrm{O})$ & -0.062 & 0.497 & 0.619 \\
\hline Innovation adoption $(\mathrm{A}) \rightarrow$ Technology $(\mathrm{T})$ & 0.232 & 0.866 & 0.387 \\
\hline Farmer as Individual $(\mathrm{I}) \rightarrow$ Technology $(\mathrm{T})$ & -0.429 & 0.917 & 0.359 \\
\hline Farmer as Individual (I) $\rightarrow$ Farm performance $(\mathrm{O})$ & 0.144 & 0.754 & 0.451 \\
\hline Technology $(\mathrm{T}) \rightarrow$ Farm performance $(\mathrm{O})$ & 0.930 & 22.719 & 0.000 \\
\hline
\end{tabular}

A crucial finding of this study is the indirect relationship between latent variables. First, it is the indirect relationship between entrepreneurship and farm business performance. The relationship displays entrepreneurship $\rightarrow$ technology $\rightarrow$ farm business performance. The relationship can also be extended, namely entrepreneurship $\rightarrow$ innovation adoption $\rightarrow$ technology $\rightarrow$ farm business performance. In this connection, technology or technology adoption functions as a bridge or mediating variable. Second, it is the indirect relationship between individual farmers and farm business performance. This last relationship is also moderated by the technology variable.

\section{Research Implication}

The results of the study show the significant role of entrepreneurship and technology adoption on the performance of lowland rice farming in the village of Mattiro Ade. However, entrepreneurship and technology adoption cannot operate in empty spaces. It requires conditions and situations that support and provide research implications as follows.

First, it is the application of technology. The application of technology in farm management is a fundamental need to increase production and reduce productivity gaps (Senthilkumar, Tesha, Mghase, \& Rodenburg, 2018). Technology is a strategic thing, that is why developed countries expressly provide production subsidies in rice farming. Ironically, farmers in developing countries, including Indonesia, trade in the factors of production that go along with the market even subject to tax (Rakotoarisoa, 2011).

The results of the study indicate that tractor and combine harvester technology can reduce production costs and provide significant profit to farmers. As shown in Figure 2, indicators of technology variable that show a significant contribution are fertilizer (T1), pesticide (T2), and harvester machine (T5), contributing costs 1.679, 1.758, and 3.495 million rupiahs per hectare (Table 4). Awareness of the use of fertilizers and pesticides is very high; however, farmers also need to learn how to use these production factors proportionally. The government needs to be more well-ordered in safeguarding fertilizer and pesticide policies. Currently, the fertilizer subsidy program has been doing well (at an average of $60 \%$ of the market price), but there are many obstacles in the field because of the limited quota and rare fertilizer. 
Pesticides are completely controlled by the market, and cannot be controlled by the government.

Second, it is the provision of the extension worker. The extension worker functions not only to provide technical assistance on farming but also serves as a bridge between farmers and the access to get information, capital and market. Extension agents function as multi-function, including facilitators, motivators, educators, mediators, and communicators for farmer groups (Sairi, 2015). The adoption of technology also requires the role of extension workers (Efendy \& Hutapea, 2014). The need for extension workers in the village of Mattiro Ade becomes an urgent need so that the technological gap in rice farming does not continue. Extension workers are also needed to help market access, so farmers are not in a weak position dealing with the middlemen. According to Rakotoarisoa (2011), when farmers receive a fair price and the expected benefits, they will be more eager to adopt new technologies. The substantive role of extension workers, competitive markets and expected profits become incentives for farmers to adopt new technologies.

Third, it is the empowerment of farmer groups. The effort serves to build communication and upgrade farmers' knowledge about farm management (Cheboi \& Mberia, 2014), technology adoption (Harinta, 2011), food security (Syarief \& Fatchiya, 2014) and environmental conservation (Waddington et al., 2014). Management in farmer groups can be a requirement for entrepreneurship training, loan, tractor assistance, field schools, or the need for solutions to farm problems. In general, the application of a tractor and combine harvester has significantly helped increase farm productivity. Nevertheless, It cannot work naturally and individually. Through farmer groups, discussion and learning processes can be developed to continuously update knowledge and skills systemically. Farmers should be more open and educated towards knowledge, businessperson (entrepreneurial) character, and should always update on new management and technology (Sudana \& Subagyono, 2012). Farmers should increase their human capital, utilize it by teaching each other farming skills in groups, to increase all other livelihood capacities including business sense (Mumuni \& Oladele, 2016). Empowerment of farmer groups facilitates technology and management assistance from the government or other parties. The existing government program of tractor assistance needs to be extended to other areas where the farmer group effectively works. Opportunities for increasing productivity of farm are even now substantially addressed, for example through the corporate farming model, by implementing the provisions of centralized land management and land consolidation (Kasijadi, Suryadi, \& Suwono, 2003; Permadhi \& Dianpratiwi, 2019).

\section{CONCLUSION AND SUGGESTION}

The implementation of the tractor and combine harvester technology can improve the performance of lowland rice farming in the village of Mattiro Ade. Farmers got average productivity of 6.62 tons of rice per hectare, a profit of 21.9 million rupiahs per hectare, with an $\mathrm{R} / \mathrm{C}$ ratio of 3.21 .

The farmers showed entrepreneurial perceptions at a moderate level. They had limitations in accessing information, getting loans or venture capital, and training in the use of tractors. Meanwhile, they also showed the perception of innovation adoption at a moderate level. The adoption of innovations by farmers dealt with barriers in terms of tractor operations, tractor prices, and the weak role of farmer groups.

Furthermore, the research shows a significant finding that describes the effect mechanism of entrepreneurship and technology adoption on the performance of rice farming. The mechanism of influence displays an indirect relationship that it is facilitated or mediated by the role of technology. Technology can make efficient use of production factors, especially fertilizers and pesticides. Furthermore, the research has important implications; it is revealed that (i) tractor and combine harvester technology is an absolute necessity for increasing productivity and rice business farming, (ii) it provides extension workers to facilitate technology adoption and foster farm management, and (iii) it empowers farmer groups to upgrade farmers' knowledge, skills and entrepreneurship in farm management.

This research acknowledges that it still raises questions related to the limited number of research 
respondents. However, researchers have attempted to prepare research designs carefully, either using a robust conceptual foundation or applying reasonable indicators.

\section{REFERENCES}

Aminah, S., Sumardjo, Lubis, D., \& Susanto, D. (2015). Strategi Peningkatan Keberdayaan Petani Kecil Menuju Ketahanan Pangan. Sosiohumaniora, 18(3), 253-261. Retrieved from

http://jurnal.unpad.ac.id/sosiohumaniora/article /download/8343/6617

Amrullah, E. R., \& Hadi, S. N. (2016). Peran dan Kontribusi Hand Tractor terhadap Efisiensi Usahatani di Banten. In Prosiding Seminar Nasional Inovasi Teknologi Pertanian (Ed.), Prosiding Seminar Nasional Inovasi Teknologi Pertanian, Banjarbaru, 20 Juli 2016 (pp. 15921598). Banjarbaru: Balitbangtan, Kementan. Retrieved from http://kalsel.litbang.pertanian.go.id/ind/images/ pdf/Semnas2016/197 eka rastiyanto.pdf

Angrist, J. D., \& Pischke, J. S. (2008). Mostly Harmless Econometrics: An Empiricist's Companion. Princeton : Princeton University Press. Retrieved from https://books.google.co.id/books?id=ztXL21Xd8 v8C

Angrist, J. D., \& Pischke, J. S. (2010). The credibility revolution in empirical economics: How better research design is taking the con out of econometrics. Journal of Economic Perspectives, 24(2), 3-30. https://doi.org/10.1257/jep.24.2.3

Bachrein, S., Ruswandi, A., \& Subarna, T. (2009). Penggunaan Traktor Roda Dua pada Lahan Padi Sawah di Jawa Barat. Agrikultura, 20(3), 191197.

https://doi.org/10.24198/agrikultura.v20i3.955

Bakhtiar, A., \& Novanda, R. R. (2018). The Relationship between the Adoption Innovation and the Communication Channel of Madura Cattle Farmers. Journal of Socioeconomics and Development, $1(2)$, https://doi.org/10.31328/jsed.v1i2.604

Boso, N., Cadogan, J. W., \& Story, V. M. (2013). Entrepreneurial orientation and market orientation as drivers of product innovation success: A study of exporters from a developing economy. International Small Business Journal, 31(1), $57-81$. https://doi.org/10.1177/0266242611400469
BPS Kabupaten Pinrang. (2019). Patampanua Subdistrict in Figures 2019. Pinrang: BPS Kabupaten Pinrang. Retrieved from https://pinrangkab.bps.go.id/publication/2019/0 9/26/a0f70e1f6ca92edf17667198/kecamatanpatampanua-dalam-angka-2019.html

BPS Pinrang Regency. (2017). Luas Panen dan Produksi Padi Menurut Kecamatan Kabupaten Pinrang Tahun 2010-2016. Retrieved February 2, 2020, from https://pinrangkab.bps.go.id/dynamictable/2017 106/22/57/luas-panen-dan-produksi-padimenurut-kecamatan-kabupaten-pinrang-tahun2010-2016.html

BPS South Sulawesi. (2016). Luas Panen, Produksi, dan Produktivitas Padi Sawah dan Padi Ladang Menurut Kabupaten/Kota di Provinsi Sulawesi Selatan, 2015. Retrieved February 2, 2020, from

https://sulsel.bps.go.id/dynamictable/2016/08/1 2/239/luas-panen-produksi-dan-produktivitaspadi-sawah-dan-padi-ladang-menurutkabupaten-kota-di-provinsi-sulawesi-selatan2015.htm

Cheboi, S., \& Mberia, H. (2014). Efficacy of Interpersonal Communication Channels in the Diffusion and Adoption of Zero Grazing Technology. International Journal of Academic Research in Business and Social Sciences. https://doi.org/10.6007/IJARBSS/v4-i9/1164

Darmadji, D., \& Suwarta, S. (2018). The Testing of Entrepreneurship as The Attempt to Remodel The Factor of Production in The Rice Farming. Journal of Socioeconomics and Development, $1(1)$, 16-24. https://doi.org/10.31328/jsed.v1i1.519

Efendy, J., \& Hutapea, Y. (2014). Analisis Adopsi Inovasi Teknologi Pertanian Berbasis Padi di Sumatera Selatan dalam Perspektif Komunikasi. Jurnal Pengkajian Dan Pengembangan Teknologi Pertanian (JPPTP), 13(2), 119-130. https://doi.org/10.21082/jpptp.v13n2.2010.p\% p

Fangohoi, L., Sugiyanto, S., Sukesi, K., \& Cahyono, E. D. (2018). Establish The Perception of Agricultural Extension Workers Through Cyber Extension As The Media Information. Journal of Socioeconomics and Development, 1(1), 32-37. https://doi.org/10.31328/jsed.v1i1.530

Ghozali, I. (2006). Aplikasi Analisis Multivariate dengan Program SPSS. Semarang, Indonesia: Publisher of Universitas Diponegoro. Retrieved from https://books.google.co.id/books?id=JdqJAQAA 
$\underline{\text { CAA] }}$

Gundry, L. K., Ofstein, L. F., \& Kickul, J. R. (2014). Seeing around corners: How creativity skills in entrepreneurship education influence innovation in business. International Journal of Management Education, 12(3), 529-538. https://doi.org/10.1016/i.ijme.2014.03.002

Harinta, Y. W. (2011). Adopsi Inovasi Pertanian Di Kalangan Petani Di Kecamatan Gatak Kabupaten Sukoharjo. Agrin, 15(2), 164-174. Retrieved from https://jurnalagrin.net/index.php/agrin/article/vi ew/192/177

Hasbi, \& Tunggal, T. (2019). Adopsi Traktor, Mesin Tanam Padi, dan Pompa Air di Sawah Pasang Surut dan Rawa Lebak. In Prosiding Seminar Nasional Lahan Suboptimal, "Smart Farming yang Berwawasan Lingkungan untuk Kesejahteraan Petani", Palembang 4-5 September 2019 (pp. 370-391). Palembang: Unsri Press. Retrieved from http://conference.unsri.ac.id/index.php/lahansu boptimal/article/download/1563/939

Herlina. (2014). Interaksi Sosial Penyuluh Pertanian sebagai Upaya Peningkatan Usaha Tani Masyarakat Petani di Kabupaten Batang. Journal of Educational Social Studies, 3(2), 30-37. https://doi.org/10.15294/jess.v3i2.6651

Heryono, M., Nugroho, I., \& Hanafie, R. (2016). Analysis of Efficiency on Rice Farming. Agricultural Socio-Economics Journal, 16(1), 31-37. https://doi.org/10.6084/m9.figshare.6265214

Kasijadi, F., Suryadi, F., \& Suwono. (2003). Pemberdayaan petani lahan sawah melalui pengembangan kelompok tani dalam perspektif Corporate Farming di Jawa Timur. Jurnal Pengkajian Dan Pengembangan Teknologi Pertanian, 6(2), 117-130. Retrieved from http://repository.pertanian.go.id/handle/123456 $\underline{789 / 1957}$

Lisa, O. (2019). The Effect of Entrepreneurial Behavior and Organizational Innovation on MSMEs Performance. JEMA: Jurnal IImiah Bidang Akuntansi Dan Manajemen, 16(2), 160172. https://doi.org/10.31106/jema.v16i2.2709

Mumuni, E., \& Oladele, O. I. (2016). Access to livelihood capitals and propensity for entrepreneurship amongst rice farmers in Ghana. Agriculture and Food Security, 5(1), 111. https://doi.org/10.1186/s40066-015-0049-x

Permadhi, D., \& Dianpratiwi, T. (2019). The
Implementation of Clique Strategy in Regrouping Program to Increase Farmer's Interest and Loyalty in Sugarcane Farming. Journal of Socioeconomics and Development, 2(2), 88-98. https://doi.org/10.31328/jsed.v2i2.1168

Purnomowati, W., \& Nugroho, I. (2010). Entrepreneurship Education is a Must. In The 2nd Indonesia International Conference on Innovation, Entrepreneurship, and Small Business (IICIES 2010) "Developing Technopreneurship and Entrepreneurial Small Businesses: A Key to Sustainable Future." Tangerang, Jakarta: Institute of Technology, Bandung (ITB), and Universitas Multimedia Nusantara (UMN). https://doi.org/10.6084/m9.figshare.6268055

Rakotoarisoa, M. A. (2011). The impact of agricultural policy distortions on the productivity gap: Evidence from rice production. Food Policy, 36(2), 147-157. https://doi.org/10.1016/j.foodpol.2010.10.004

Rangkuti, P. A. (2010). Peran Komunikasi dalam Modernisasi Pertanian Berbasis Koperasi. Jurnal Komunikasi Pembangunan, 8(1), 42-48. Retrieved from http://journal.ipb.ac.id/index.php/jurnalkmp/arti cle/download/5694/4322

Sairi, A. (2015). Peran Petugas Penyuluh Pertanian Dalam Mengembangkan Budidaya Padi Di Desa Sumber Sari Kecamatan Loa Kulu Kabupaten Kutai Kartanegara. EJournal IImu Komunikasi, 3(2), 150-164. Retrieved from http://ejournal.ilkom.fisip-

unmul.ac.id/site/?p=1947\#

Senthilkumar, K., Tesha, B. J., Mghase, J., \& Rodenburg, J. (2018). Increasing paddy yields and improving farm management: results from participatory experiments with good agricultural practices (GAP) in Tanzania. Paddy and Water Environment, 16(4), 749-766. https://doi.org/10.1007/s10333-018-0666-7

Sudana, W., \& Subagyono, K. (2012). Kajian Faktor-faktor Penentu Adopsi Inovasi Pengelolaan Tanaman Terpadu Padi melalui Sekolah Lapang Pengelolaan Tanaman Terpadu. Jurnal Pengkajian Dan Pengembangan Teknologi Pertanian, 15(2), 94-106. Retrieved from

http://ejurnal.litbang.pertanian.go.id/index.php/ jpengkajian/article/view/2524/2165

Sugiyono. (2016). Metode Penelitian Kuantitatif Kualitatif dan R and D (23rd ed.). Alfabeta, Bandung. Retrieved from 
https://books.google.co.id/books?id=0xmCnQA ACAA]

Suhendrata, T. (2010). Peran Inovasi Teknologi Pertanian dalam Peningkatan Produktivitas Padi Sawah untuk Mendukung Ketahanan Pangan. Prosiding Seminar Nasianal Teknik Pertanian 2008, (November 2008), 1-15. Retrieved from http://repository.ipb.ac.id/bitstream/handle/123 456789/8461/Tota Suhendrata .pdf

Sulistyo, H., \& Siyamtinah. (2016). Innovation capability of SMEs through entrepreneurship, marketing capability, relational capital and empowerment. Asia Pacific Management Review, 21(4), 196-203. https://doi.org/10.1016/j.apmrv.2016.02.002

Suyatno, A., Imelda, I., \& Komariyati, K. (2018). Pengaruh Penggunaan Traktor Terhadap Pendapatan dan Penggunaan Tenaga Kerja pada Usahatani Padi di Kabupaten Sambas. AGRARIS: Journal of Agribusiness and Rural Development Research, 4(2), 91-100. https://doi.org/10.18196/agr.4264

Syarief, R., \& Fatchiya, A. (2014). Kajian Model Pemberdayaan Ketahanan Pangan di Wilayah Perbatasan Antar Negara (Assessment of Food Security Empowerment Modelin Inter-State Border). Jurnal Ilmu Pertanian Indonesia (JIPI), 19(1), 9-13. Retrieved from http://journal.ipb.ac.id/index.php/JIPI/article/vi ew/8400

Thorbecke, E., \& Van Der Pluijm, T. (1993). Rural
Indonesia: Socio-economic Development in a Changing Environment. NYU Press. Retrieved from

https://books.google.co.id/books?id=Ee2n9IG4 EH4C

Triyono, B., Laksani, C. S., Zulhamdani, M., Nadhiroh, I. M., \& Ariana, L. (2018). The Identification of Research Priority in The Field of Food Security. Journal of Socioeconomics and Development, 1(2), 88-99. https://doi.org/10.31328/jsed.v1i2.729

Waddington, H., Snilstveit, B., Hombrados, J., Vojtkova, M., Phillips, D., Davies, P., \& White, H. (2014). Farmer Field Schools for Improving Farming Practices and Farmer Outcomes: A Systematic Review. (Sandra Jo Wilson, Ed.), Campbell Systematic Reviews (Vol. 10). London: Wiley. https://doi.org/10.4073/csr.2014.6

Wei, X., Liu, X., \& Sha, J. (2019). How does the entrepreneurship education influence the students' innovation? Testing on the multiple mediation model. Frontiers in Psychology, 10(July), 1-10. https://doi.org/10.3389/fpsyq.2019.01557

Widiyanti, E., Karsidi, R., Wijaya, M., \& Utari, P. (2019). Farming occupation in the views of farmer families in rural area. In IOP Conference Series: Materials Science and Engineering (Vol. 633, pp. 1-6). Institute of Physics Publishing. https://doi.org/10.1088/1757$\underline{899 X / 633 / 1 / 012060}$ 